ZOOLOGIA 27 (6): 902-908, December, 2010

doi: $10.1590 /$ S1984-46702010000600011

\title{
Microhabitat use by Cnemidophorus vacariensis (Squamata: Teiidae) in the grasslands of the Araucaria Plateau, Rio Grande do Sul, Brazil
}

\author{
Rodrigo Caruccio; ; Renata C. Vieira² \& Laura Verrastro²
}

\author{
${ }^{1}$ Rua Dr Salvador França 1070, Jardim Botânico, 90690-000 Porto Alegre, RS, Brazil. E-mail: rodrigocaruccio@gmail.com \\ ${ }^{2}$ Departamento de Zoologia, Universidade Federal do Rio Grande do Sul. Avenida Bento Gonçalves 9500, prédio 43435, \\ sala 107, Campus do Vale, 91501-970 Porto Alegre, RS, Brazil. E-mail: renatacva@yahoo.com.br; lauraver@ufrgs.br
}

\begin{abstract}
Microhabitat use by Cnemidophorus vacariensis Feltrim \& Lema, 2000 as studied between October 2006 and September 2007 in two rocky formations in the municipality of Bom Jesus. The area was searched randomly between 8:00 am and 6:00 pm and the microhabitat used by the lizards was recorded. Our observations revealed that C. vacariensis has terrestrial habits and prefers open areas. Burrows are the main microhabitat used by the species (56.38\%). When in activity, $54.76 \%$ of the individuals were observed under rocks, and $38.1 \%$ on the ground where herbaceous vegetation was present. The rocks under which they constructed their burrows were on average significantly thicker during warmer seasons temperatures $(\bar{x}=13,45 \mathrm{~cm})$ with respect to colder seasons $(\bar{x}=9,85 \mathrm{~cm})$. The rocks selected by the adults $(\bar{x}=$ $12.94 \mathrm{~cm}$ ) were on average significantly thicker than those selected by the juveniles $(\bar{x}=9.86 \mathrm{~cm})$. There were no statistically significant differences between sexes with respect to rock thickness.
\end{abstract}

KEY WORDS. Burrows; rocks; thermoregulation, shelter.

The relationship between habitat use and lizard thermoregulation is as important in the ecology of lizards as the environmental temperature itself (COWLEs \& BOGERT 1944, HuEY 1982). Several ectotherms keep their body temperatures relatively constant by selecting thermally adequate microhabitats Kearney 2002).

Variations in microclimate may determine microhabitat selection not only during activity (HuEY 1982, 1991), but also during periods of inactivity (HuEY et al. 1989, Weвв \& SHINE 1998, 2000, Kearney 2002). Thermal regimes found inside shelters are different from those experienced on the ground during activity (Huey et al. 1989, KeARNeY 2002). Empirical and biophysical analyses of temperatures under rocks of different sizes and shapes have demonstrated that the thickness of a rock used as shelter has a dominant effect on the body temperature of ectotherms (Huey 1991). Thus, the selection of shelters that are thermally appropriate may be important to terrestrial ectotherms, since these animals are inactive for long periods of time. In addition, several their behavioral and physiological processes are temperature-dependent (HuEY 1982).

Several studies have demonstrated that factors such as interespecific competition (SCHoener 1977, Salzburg 1984, NúÑ̃z et al. 1989), predation (GibBons \& LilLywhite 1981), size and morphology of the lizard (Marcellini \& Mackey 1970, Asplund 1974, SCHeibe 1987), and seasonal and ontogenetic variations (PAULISSEN 1987) may influence microhabitat use. Adolph (1990) concluded that microhabitat use by a particular species of lizard reflects an overlap between thermally appropriate conditions for the species' average size and behavioral preferences. Mesquita \& Colli (2003), analyzing the geographical variation in the ecology of Cnemidophorus species from three Brazilian open area biomes (Cerrado, Caatinga, and Amazonic Savana), stated that individuals of a species use similar microhabitats regardless of the biome they inhabit. The little variation observed among populations is probably a result of differences in the availability of appropriate microhabitats among regions, and not due to the presence of a specific microhabitat.

Cnemidophorus vacariensis Feltrim \& Lema, 2000 inhabits rocky formations located in high altitude grasslands (DIBERNARDO et al. 2003), being apparently endemic of the Araucaria Plateau in southern Brazil. The lack of enough information about the biology and ecology of this species in the presence of habitat alteration has placed it in the vulnerable category of the Reference List of Endangered Fauna of Rio Grande do Sul (Lista de Referência da Fauna Ameaçada de Extinção do Rio Grande do Sul; Marques et al. 2002). The species is also included in the National List of the Brazilian Endangered Fauna (Brasil 2003), and in the Red Book of the Endangered Fauna of Rio Grande do Sul and Parana (Мiкich \& Bérnils 2004).

The main goal of the present study was to ascertain and analyze microhabitat use in a population of C. vacariensis, focusing specifically on the following questions: 1) Are there seasonal variations in microhabitat use? 2) Are there ontogenetic and intersexual variations in microhabitat use? 3) Do individuals of $C$. vacariensis actively select places where to construct a shelter (burrow)? 


\section{MATERIAL AND METHODS}

This study was carried out in the municipality of Bom Jesus, located in the physiographic region of Campos de Cima da Serra, state of Rio Grande do Sul. The climate is classified as temperate humid, with a mean rainfall of $1545 \mathrm{~mm}$, mean temperature of the coldest month of $10^{\circ} \mathrm{C}$, and mean annual temperature of $14.4^{\circ} \mathrm{C}$ (MALUF 2000). Winters are characterized by the frequent frosts and eventual snow showers. The region presents two main vegetations: the mixed ombrophilous forest with several elements associated with Araucaria angustifolia (Bertol.) Kuntze and the grassland, uniform in landscape but heterogeneous in species composition. For a detailed description see Boldrini (1997). The study site (UTM 22 J 528218/ 6868725 ) is characterized by the presence of two rocky formations, with a total area of $1.3 \mathrm{ha}, 950 \mathrm{~m}$ of height, and vegetation composed by shrubs and grasses.

Field work, carried out monthly, was performed between October 2006 and September 2007. We conducted random searches in the area from 8:00 am to $6: 00 \mathrm{pm}$. The following information was recorded for each lizard observed: 1) time of observation; 2) microhabitat used when the lizard was first seen; 3) activity level. In addition, for all specimens captured, we recorded the Snout-vent length (SVL), using a caliper Mitutoyo ${ }^{\circledR}$ with precision of $0.02 \mathrm{~mm}$, age class and sex.

The microhabitat was recorded following four categories: 1) burrow, 2) under rock, 3) on the ground where herbaceous vegetation predominates, and 4 ) under shrubs. Burrows of $C$. vacariensis, constructed under rocks in sandy substrates, are easily recognizable. Thus, the category, "under rocks" implies that the animal was underneath a rock, but not in a burrow. Lizards were considered active when they were engaged in any type of activity or movement and inactive when they were standing still (little or no reaction) and sheltered in burrows.

Individuals were classified into two classes according to their age: adults or juveniles.

Adult animals were identified according to the minimum reproductive size for the species (males: SVL $>48.8 \mathrm{~mm}$, females: SVL > $57.4 \mathrm{~mm}$ ) (Rezende-Pinto et al. 2009). Sex was determined only for adult individuals following REzendE-PINTO et al. (2009). According to the authors, males present black spots on the abdomen and pouch, and a yellowish coloration on the first rows of ventral scales, whereas females do not present spots on the abdomen and are larger than males.

Tthe following environmental temperatures were recorded hourly: air temperature (TA), at $10 \mathrm{~cm}$ from ground surface, and substrate temperature (TS). These temperatures were measured under the sun and always at the same site. Temperature curves for each season were obtained using the hourly mean temperatures recorded monthly. Seasons were classified as: spring (October, November, and December 2006), summer (January, February, and March 2007), autumn (April, May, and June 2007), and winter (July, August, and September 2007).
A bivariate analysis through crossed tables related to Chisquare test and Correspondence Analysis were performed to identify relationships among the use of different microhabitats by C. vacariensis and seasons, sexes, and age classes. In addition, differences in frequency distribution of microhabitat use for active lizards among these variables were evaluated using the Kolmogorov-Smirnov test two-by-two (SiEgel 1975).

In order to test whether individuals of $C$. vacariensis select the rocks under which they construct their burrows, we measured the thickness $(\mathrm{cm})$ of each rock that had a lizards sheltered in burrows (Huey et al. 1989, SABo 2003). A t-test was performed to compare the mean thickness of the rocks among seasons, sexes, age classes, reproductive and non-reproductive periods, and females with and without eggs. It is important to mention that data analysis between age classes and sexes of $C$. vacariensis was carried out only for captured specimens.

\section{RESULTS}

A total of 94 records of C. vacariensis were obtained throughout the study, encompassing 39 adults ( 25 males and 14 females), 36 juveniles, and 19 non-captured specimens (in which case it was not possible to identify sex or age). From this total, 40 specimens were in activity (42.55\%), corresponding to eight adults (six males and two females) and 14 juveniles. The mean SVL of the females was $67.00 \pm 5.10 \mathrm{~mm}$, that of males was 58.93 $\pm 6.54 \mathrm{~mm}$, and that of juveniles was $44.17 \pm 7.02 \mathrm{~mm}$. Four oviparous females were recorded during the spring.

Seasonally, lizard records were distributed as follows: spring - 14 active specimens ( 3 juveniles, 4 males, 2 females, and 5 non-captured) and 14 inactive (no juveniles, 8 males, and 6 females); summer -17 active specimens (13 juveniles, 1 male, and 3 non-captured), and 14 inactive ( 8 juveniles, 3 males, and 3 females); autumn -3 active specimens ( 1 juvenile and 2 non-captured) and 16 inactive (10 juveniles, 3 males, and 3 females); winter -6 active specimens (4 juveniles, 1 male, and 1 non-captured) and 10 inactive (5 juveniles and 5 males).

The Mean environmental temperatures (TA and TS) varied significantly throughout the year, demonstrating the seasonality of the region (Fig. 1).

Considering all recorded individuals of $C$. vacariensis, the main microhabitat used during the study was "burrow" (56.38\%), followed by "underneath a rock" (24.47\%), and "on the ground with herbaceous vegetation" (18.06\%), independent of activity level. Only one lizard was seen walking "under herbaceous vegetation" (1.06\%). All specimens found under rocks were on sandy substrate. No individual was recorded thermoregulating under rocks. Thus, we decided to remove this habitat from the study.

During spring, lizards emerged from their burrows between 10:00 and 11:00 am. When the surrounding temperatures (12:00 am to 2:00 pm) were highest, no lizards were observed in environments that were directly exposed to the sun (microhabitat "on the ground under herbaceous vegetation") (Fig. 2). 


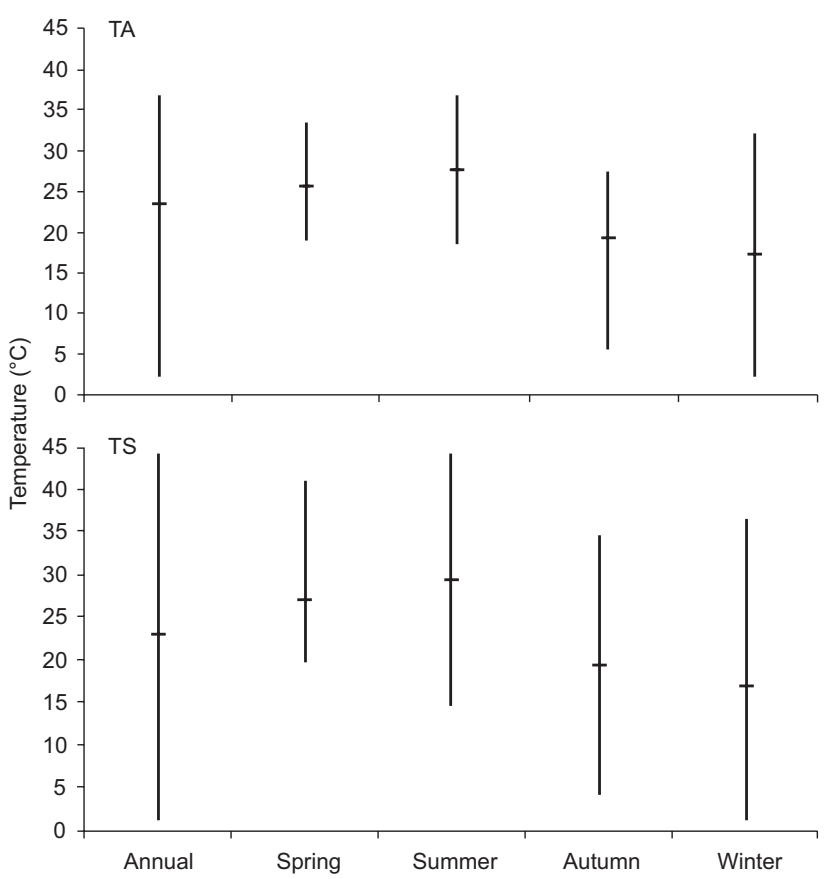

Figure 1. Annual and seasonal variation of environmental temperatures recorded in the study area in the municipality of Bom Jesus between October 2006 and September 2007. (TA) Air temperature, (TS) substrate temperature. Bars represent mean temperatures.

During summer, specimens left their burrows between 9:00 am and 10:00 am and were directly exposed to the sun only until 11:00 am. When environmental temperatures were high, the number of records was much reduced, and the few animals observed were sheltered underneath rocks (Fig. 2).

During autumn and winter, when environmental temperatures were low, lizards stayed in their burrows for most of the day (Fig. 2). This tendency is more evident if we exclude September from the winter analysis. In this month, the environmental temperatures recorded were higher with respect to July and August. Thus, from a total of eight records, six lizards were found in burrows, and two under rocks.

Crossed tables indicate a significant relationship between juvenile lizards and he microhabitat "under rock" (adjusted residual $\left.=2.9, \chi^{2}=0.024\right)$. Overall, the correspondence analysis revealed that adults tend to use the microhabitat "on the ground with herbaceous vegetation" more frequently (Fig. 3). For all other crossings there was no evidence of an interaction between microhabitat use and sex, age, or season (for all $\chi^{2}>0.05$ ).

When only lizards in activity were taken into consideration $(n=40), 54.76 \%$ were found "under rock", 38.1\% "on the ground with herbaceous vegetation", $4.76 \%$ in "burrows", and $2.38 \%$ "under shrubs". During summer and winter, seasons with extreme temperatures, the majority of lizards used

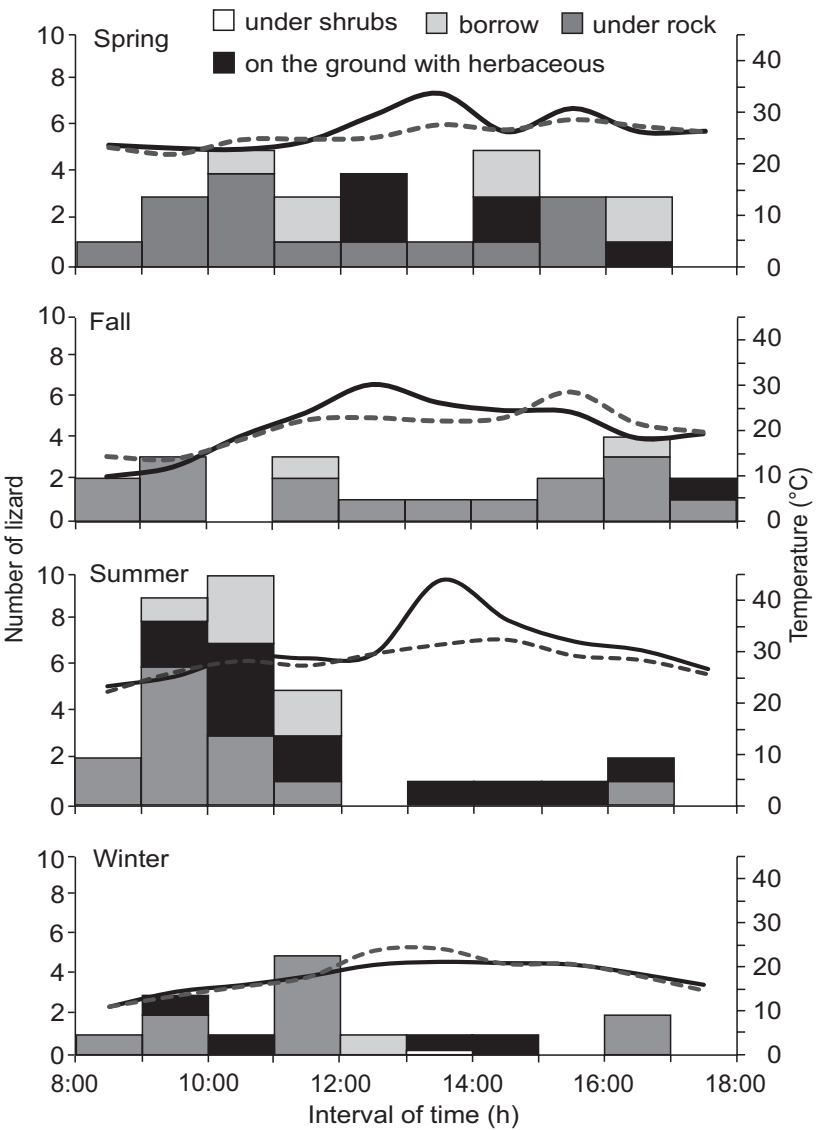

Figure 2. Microhabitat use by C. vacariensis and hourly mean of environmental temperatures (air temperature: continuous line, substrate temperature: broken line) throughout the seasons in the study area, municipality of Bom Jesus between October 2006 and September 2007.

the microhabitat "under rock" (Fig. 4). In spring and autumn, specimens of C. vacariensis were more exposed to the sun, using predominantly the microhabitat "ground with herbaceous vegetation" (Fig. 4). However, there were no statistically significant differences in microhabitat use by active lizards among seasons, age classes and sexes (Kolmogorov-Smirnov, for all $\mathrm{p}$ $>0.05$ ). It is important to highlight that four of the six records of active lizards during the winter were obtained in September, when environmental temperatures were higher in comparison with other months in the same season.

The mean thickness of the rocks under which individuals of $C$. vacariensis built their burrows are listed in table I. These rocks were significantly thicker in warmer seasons when compared with rocks selected during colder seasons $(\bar{x}$ spring and summer $=13.45 \mathrm{~cm}, \overline{\mathrm{x}}$ autumn and winter $=9.85, \mathrm{t}=2.739$, $\mathrm{df}=49, \mathrm{p}=0.009$ ). Adult lizards chose rocks that were significantly thicker on average than the rocks selected by juveniles 


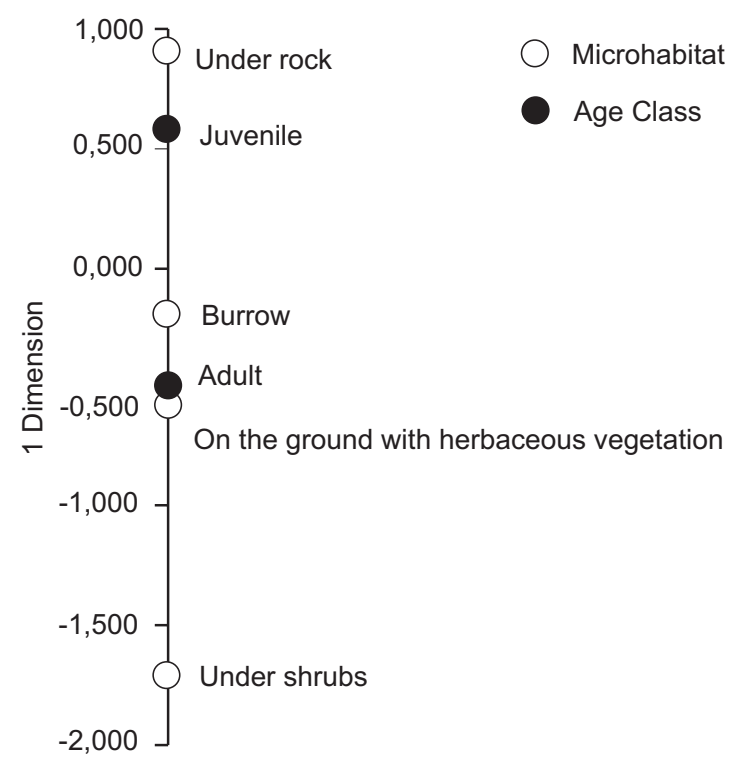

Figure 3. Correspondence Analysis between age classes and different microhabitats used by $C$. vacariensis in the study area,municipality of Bom Jesus between October 2006 and September 2007.

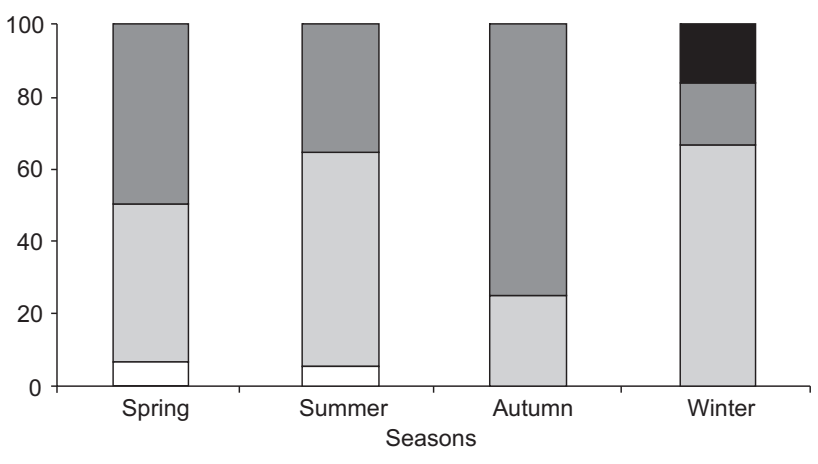

$\square$ Burrow $\square$ Under rock $\square$ On the ground with herbaceous vegetation $\square$ Under shrubs Figure 4. Use of microhabitat by active $C$. vacariensis during the seasons in the study area, municipality of Bom Jesus between October 2006 and September 2007.

$(\overline{\mathrm{x}}$ adults $=12.94 \mathrm{~cm}, \overline{\mathrm{x}}$ juveniles $=9.86 \mathrm{~cm}, \mathrm{t}=2.268, \mathrm{df}=49, \mathrm{p}$ $=0.028)$. No statistically significant differences were observed between the thickness of rocks chosen by males and females $(\bar{x}$ males $=14.06 \mathrm{~cm}, \bar{x}$ females $=11.01 \mathrm{~cm}, t=1.632, \mathrm{df}=27$, $\mathrm{p}=0.114$ ) when warmer and colder seasons where compared.

During the reproductive season (which coincides with the spring months, Rezende-Pinto et al. 2009), rocks used by females to build burrows were on average thinner than the rocks chosen by males, although this difference was not statistically significant $(\bar{x}$ males $=15.3 \mathrm{~cm}, \bar{x}$ females $=9.63 \mathrm{~cm}, \mathrm{t}=$ $2.028, \mathrm{df}=10, \mathrm{p}=0.070)$. The same pattern was observed for
Table I. Thickness of the rocks under which C. vacariensis constructed their burrows throughout the seasons in the study area, municipality of Bom Jesus, Rio Grande do Sul, between October 2006 and September 2007.

\begin{tabular}{cccc}
\hline \multirow{2}{*}{ Season } & \multicolumn{2}{c}{ Thickness of the rock $(\mathrm{cm})$} & \multirow{2}{*}{ Sample Size } \\
\cline { 2 - 3 } Spring & & Amplitude & \\
Males & $15.3 \pm 5.88$ & $7.0-25.0$ & 9 \\
Females & $9.63 \pm 2.24$ & $7.3-13.0$ & 5 \\
Juveniles & - & - & - \\
Total & $12.94 \pm 5.40$ & $7.0-25.0$ & 15 \\
Summer & & & \\
Males & $16.33 \pm 2.52$ & $14.0-19.0$ & 3 \\
Females & $13.33 \pm 9.45$ & $6.0-24.0$ & 3 \\
Juveniles & $13.14 \pm 4.45$ & $8.0-21.0$ & 7 \\
Total & $13.92 \pm 5.27$ & $6.0-24.0$ & 13 \\
Autumn & & & \\
Males & $13.67 \pm 1.15$ & $13.0-15.0$ & 3 \\
Females & $11.33 \pm 6.11$ & $6.0-18.0$ & 3 \\
Juveniles & $7.80 \pm 3.99$ & $2.0-14.0$ & 10 \\
Total & $9.56 \pm 4.56$ & $2.0-18.0$ & 16 \\
Winter & & & 5 \\
Males & $11.2 \pm 1.92$ & $9.0-14.0$ & 5 \\
Females & - & - & - \\
Juveniles & $9.4 \pm 4.50$ & $3.0-15.0$ & 5 \\
\hline Total & $10.3 \pm 3.40$ & $3.0-15.0$ & 10 \\
\hline
\end{tabular}

oviparous females, which occupied thinner rocks than nonoviparous females ( $\bar{x}$ oviparous females $=8.38 \mathrm{~cm}, \bar{x}$ non-oviparous females $=12.13 \mathrm{~cm}, \mathrm{t}=-1.012, \mathrm{df}=9, \mathrm{p}=0.338$ ).

During the reproductive period females used rocks that were thinner than the rocks used during the non-reproductive period $(\bar{x}$ reproductive $=9.63 \mathrm{~cm}, \bar{x}$ non-reproductive $=12.33$ $\mathrm{cm})$. Males showed an opposite trend, selecting thicker rocks during the reproductive period $(\bar{x}$ reproductive $=15.3 \mathrm{~cm} ; \bar{x}$ nonreproductive $=13.27 \mathrm{~cm}$ ). However, these differences were not statistically significant (females: $t=0.802, d f=9, p=0.443$; males: $\mathrm{t}=0.802, \mathrm{df}=9, \mathrm{p}=0.443$ ).

In five occasions we observed the presence of lizards (two females and three juveniles) sheltered under rocks in burrows shaped as small galleries.

It is important to mention that in August 2007, a fire used to clean up the vegetation burned almost the entire study area. Even though this fire eliminated the herbaceous and shrubby vegetation almost entirely, individuals of $C$. vacariensis were found alive, hiding under rocks and sheltered in their burrows. 


\section{DISCUSSION}

Rocks were the resource of the main microhabitats used by the C. vacariensis population in the municipality of Bom Jesus. This is not surprising because the rocky formations are the dominant habitat in the study region. Mesquita \& Colli (2003) mentioned that Brazilian species of Cnemidophorus Wagler, 1830 use similar microhabitats independent of the biome where they live. The small variations observed among populations are a result of differences in availability of microhabitat among regions, and do not reflect a preference for a specific microhabitat.

Data presented here has revealed that $C$. vacariensis is a terrestrial lizard with a strong preference for open areas, a tendency observed in other species in the genus (Mesquita \& Colli 2003).

Cnemidophorus vacariensis was recorded most of the time hiding under rocks or sheltered in burrows, especially when temperatures were extreme. Ground activities (basking) were seldom observed (Fig. 2). Rocks, due to their high conductivity and capacity to store heat, are a valuable thermal resource for ectotherms in open areas (SABO 2003). They can be particularly important in regions such as Bom Jesus, where heat sources vary strongly due to the seasonality of the region (Fig. 1). Since rocky formations are characteristically open environments, rocks are also important shelters where $C$. vacariensis can escape from potential predators. According to Acosta \& Martori (1990), when environmental temperatures are not favorable for lizard activities, staying in a shelter is an important strategy to avoid predation.

Thus, thermoregulation under rocks may be advantageous for C. vacariensis from the adaptive point of view, due to the physical characteristics of this species' habitat. According to ADOLPH (1990), natural selection favors the use of microhabitats that are appropriate for a thermal local environment.

The dark coloration of C. vacariensis may also help thermoregulation under rocks, optimizing quick heat absorption when heat becomes available. It is known that the coloration pattern of an animal is a type of thermoregulation mechanism that helps inthe capture of heat from the environment. In general, animals adapted to low temperatures have a dark tegument (SмITH 1979).

Huey et al. (1989) stated that ectotherms in some circumstances can thermoregulate more effectively in shelters than in open areas. Depending on the thermal properties of the shelters, these animals have different opportunities for thermoregulation, thus experimenting body temperatures that might be very different from those associated with activities on the ground (Kearney 2002). Accordingly, the seemingly careful thermoregulation of active ectotherms on the ground could represent an incomplete and potentially misleading view of their thermal biology throughout the day (Huey et al. 1989).

The selection of shelters has a better choice on body temperature of ectotherms, and on their thermal physiology (HuEY
1991). According to Huey et al. (1989), the type of shelter selected should correspond to the thermoregulatory needs of the animal.

Microclimate variations inside shelters result from the differential radiation of heat stored in substrates of different sizes and composition (SABo 2003). For example, the rates of heat transfer between the tip and the base of thick rocks are low, and the base of thick rocks will always be cool (with exception of the borders). By contrast, heat transfer between the tip and the base of thin rocks is fast, and under rock temperatures are close to ground surface temperatures at any time of the day (Huey et al. 1989).

Individuals of $C$. vacariensis selected thicker rocks to construct their burrows during warm periods (Spring and Summer). This seasonal variation suggests that the temperature affects quantitative changes in the types of rocks under which $C$. vacariensis builds burrows.

During the warmest hours of a summer day, and in the cold days of the autumn and winter, the number of lizards recorded in activity or sheltered in burrows was very reduced (see Fig. 2). This fact, in addition to the records of subterraneous burrows, may indicate that these animals may search for large rocks and/or deep burrows to protect themselves from inadequate temperatures. According to Feltrim (2002), C. lacertoides, another species found underneath rocks in Rio Grande do Sul, builds sinuous galleries in the rocky areas where it lives. Thus, in addition to quantitative changes, possible qualitative changes in the shelters used by C. vacariensis may be thermally driven.

The types of rocks selected by $C$. vacariensis individuals to construct their burrows could be a result of differences in energetic demands among individuals. The thickness of the rocks used differed significantly between juveniles and adults. Warmer shelters, due to the selection of thinner rocks, may maximize the gain of available energy needed by the juveniles to grow (SABo 2003).

Rocks selected by males were thicker than those selected by females, although these differences are not statistically significant. Females may have chosen thinner rocks than males during the reproductive season to enhance digestive efficiency and drive energy for reproduction during the period of inactivity. In this case, warmer shelters might allow females to enhance their seasonal egg production of (SABO 2003), and following that, egg thermoregulation. The fact that oviparous females of $C$. vacariensis selected thinner rocks in comparison with non-oviparous females supports this idea. Conversely, males of $C$. vacariensis, due to their more active lifestyle, probably expend more energy on a daily basis, what allows them to choose colder shelters and to avoid additional metabolic costs during inactivity periods (SABO 2003).

Concluding, C.vacariensis is a terrestrial species with a strong preference for open areas. Microhabitats formed by the combination of "rock X sandy substrate" are shelter sites (places of burrow construction) and refuge (extreme environmental 
temperatures, burning, and potential predators) for $C$. vacariensis, in addition to being an important resource for thermoregulation. Moreover, microhabitat use may have functional consequences for $C$. vacariensis due to its role in the regulation of the body temperature, since the lizards selected shelters adequate to their thermoregulatory needs.

\section{ACKNOWLEDGEMENTS}

We would like to thank Márcio B. Martins and Clóvis Bujes for the constant discussion, revisions, and suggestions throughout this study. We also thank Carlos F.D. da Rocha and Roberto B. de Oliveira for their valuable contributions; the UFRGS and its Programa de Pós-Graduação em Biologia Animal, and all those who helped in the field work, especially Gabriele Volkmer. Baesa funded the study through the project "Programa de Monitoramento da fauna pós-enchimento do Reservatório da Área de Influência do AHE Barra Grande" in collaboration with Instituto de Biociências/UFRGS.

\section{LITERATURE CITED}

Acosta, J. \& R. Martori. 1990. Ecologia de uma poplación de Teius oculatus (Sauria: Teiidae) de Rio Cuarto (Córdoba): II Utilización espacio-temporal y relaciones térmicas. Cuadernos de Herpetologia 5 (4): 19-24.

Adolph, S.C. 1990. Influence of behavioral thermoregulation on microhabitat use by two Sceloporus lizards. Ecology 71: 315-327.

Asplund, K,K. 1974. Body Size and Habitat Utilization in Whiptail Lizards (Cnemidophorus). Copeia 3: 695-703.

BoldRINI, I.I. 1997. Campos do Rio Grande do Sul: caracterização fisionômica e problemática ocupacional. Boletim do Instituto de Biocienciências Universidade Federal do Rio Grande do Sul 56: 1-39.

BRASIL. 2003. Lista Nacional das Espécies da Fauna Brasileira Ameaçada de Extinção. Brasília, Instituto Brasileiro do Meio Ambiente e dos Recursos Renováveis. Available online at: http://www.ibama.gov.br/fauna/downloads/lista\%20spp.pdf [Accessed: 25.XI.2009]

Cowles, R.B \& C.M. Bogert. 1944. A preliminary study of the thermal requirements of desert reptiles.

Bulletin of the American Museum of Natural History 83: 265-296.

DI-Bernardo, M.; M. Borges-Martins \& R.B. Oliveira. 2003. Répteis, p. 165-188. In: C.S. Fontana; G.A. Bencke \& R.E. Reis (Eds). Livro vermelho da fauna ameaçada de extinção no Rio Grande do Sul. Porto Alegre, EDIPUCRS, 632p.

Feltrim, A.C. 2002. Dimorfismo Sexual em Cnemidophorus lacertoides (Squamata, Teiidae) do Sul da América do Sul. Phyllomedusa 1 (2): 75-80.

Feltim, A.C. \& T. Lema. 2000. Uma nova espécie de Cnemidophorus Wagler, 1830 do Estado do Rio Grande do Sul, Brasil (Sauria, Teiidae). Biociências 8 (1): 103-114.
GibBons, J.R.H. \& H.B. LilLywhite. 1981. Ecological segregation, color matching, and speciation in lizard of the Amphibolurus decresii complex (Lacertilia, Agamidae). Ecology 62: 15731584.

Huey, R.B. 1982. Temperature, physiology, and the ecology of reptiles, p. 25-91. In: C. Gans \& F. H. Pough (Eds). Biology of the Reptilia. New York, Academic Press, 345p.

HuEY, R.B. 1991. Physiological consequences of habitat selection. The Americam Naturalist 137: S91-S115.

Huey, R.B.; C.R. Peterson; S.J. Arnold \& W.P. Porter. 1989. Hot rocks and not-so-hot rocks: retreat-site selection by garter snakes and its thermal consequences. Ecology 70: 931-944.

KeARney, M. 2002. Hot rocks and much-too-hot rocks: seasonal patterns of retreat-site selection by a nocturnal ectotherm. Journal of Thermal Biology 27 (2002): 205-218.

Maluf, J.R.T. 2000. Nova classificação climática do Estado do Rio Grande do Sul. Revista Brasileira de Agrometeorologia 8 (1): 141-150.

Marcellini, D. \& J.P. Mackey. 1970. Habitat preferences of the lizards Sceloporus occidentalis and S. graciosus (Lacertilia: Iguanidae). Herpetologica 26: 51-56.

Marques, A.A.B; C.S. Fontana; E. Vélez, G.A Bencke; M. Schneider \& R.E. ReIs. 2002. Lista das Espécies de Fauna Ameaçadas de Extinção no Rio Grande do Sul. Porto Alegre, FZB/MCTPUCRS/PANGEA, 52p.

Mesquita, D.O. \& G.R. Colli. 2003. Geografical variation in the ecology of populations of some brazilian species of Cnemidophorus (Squamata, Teiidae). Copeia 2: 285-298.

МıкісH, S.B. \& R.S. BérniLS. 2004. Livro vermelho da fauna ameaçada do Estado do Paraná. Curitiba, Instituto Ambiental do Paraná, 764p.

NúÑez, H.; P.A. Marquet; R.G. Medel \& F.M. Jaksic. 1989. Niche relationships between two sympatric Liolaemus lizards in a fluctuating environment: the "lean" versus "feast" scenario Journal of Herpetology 23: 22-28.

Paulissen, M. 1987. Optimal foraging and intraspecific diet differences in the lizard Cnemidophorus sexlineatus. Oecologia 71 (3): 439-446.

Rezende-Pinto F.M.; L. Verrastro; J.C. Zanotelli \& P.C.R. Barata. 2009. Reproductive biology and sexual dimorphism in Cnemidophorus vacariensis (Sauria, Teiidae) in the fields of the Araucaria Plateau, state of Rio Grande do Sul, Brazil. Iheringia, Série Zoologia 99 (1): 82-91

SABO, J.L. 2003. Hot rocks or no hot rocks: overnight retreat availability and selection by a diurnal lizard. Oecologia 136: 329-335.

Salzburg, M.A. 1984. Anolis sagrei and Anolis cristatellus in southern Florida: a case study in interspecific competition. Ecology 65: 14-19.

SCHeibe, J.S. 1987. Climate, competition, and the structure of temperate zone lizard communities. Ecology 68: 1424-1436.

Schoener, T,W. 1977. Competition and the niche, p. 35-136. In: C. Gans \& D.W. TinkLE (Eds). Biology of Reptilia. New York, 
Academic Press, vol. 7, 554p.

SIEGEL, S. 1975. Estatística não paramétrica para as ciências do comportamento. Rio de Janeiro, McGraw-Hill, 350p.

Sмітн, H.M. 1979. Handbook of Lizards: Lizards of the United States and of Canada. Binghamton, Comstock Publishing Company, 557p.
Weвb, J.K. \& R. Shine. 1998. Using thermal ecology to predict retreat-site selection by an endangered snake species. Biological Conservation 86: 233-242.

Webb J.K. \& R. Shine. 2000. Paving the way for habitat restoration: can artificial rocks restore degraded habitats for endangered reptiles? Biological Conservation 92: 93-99.

Submitted: 25.XI.2009; Accepted: 18.IX.2010.

Editorial responsibility: Kleber del Claro 